\title{
The Process of Implementing the Accounting Harmonisation in the Italian Local Governments: The Case of Prato
}

\author{
Matteo Pozzoli* and Stefano Ranucci
}

The Università degli Studi di Napoli "Parthenope", Italy

\begin{abstract}
The purpose of this paper is to describe the experience of the Municipality of Prato (Comune di Prato) in adopting the new accounting model proposed by the harmonisation process of local governments. According to the theoretical model developed by institutional theories, the implementation of accounting reforms is connected to external stimuli that are exercised on an organization, and by the capability to interpret and implement the principles and requirements included in reforms. In accordance with the literature, the paper describes the process of implementation of the reform carried out by the Municipality of Prato, assessing the external and internal elements that have influenced the implementation. The paper analyses the most significant conditions and reactions to the change during the experimentation, which should introduce the reform. In this two year period, the new adopter has the chance to play a pro-active role in the process. This circumstance contributes to the development of the research, as it adds a component (the pro-active role), that has not been considered by the literature.
\end{abstract}

Keywords: Local Governments, Public Administration, accounting reform, institutionalism

\section{Introduction}

The aim of this paper is to outline the process of implementation of the accounting reform of the Italian local governments (LGs) with the case study of the Municipality of Prato.

There is no research, up till today, upon the content of the LGs' accounting reform that started in 2010. The paper is part of the studies on the processes of reform of the public sector accounting, a relevant element of any New Public Management (NPM) reform process.

To test the effects of the accounting reform, a two year experimentation period was arranged for a limited number of LGs. The experimentation period aims at: (a) verifying the capability of the new accounting system to produce the information required to better manage the local public finance; (b) identifying any critical aspects of the reform and (c) evaluating the results of changes in accounting rules.

The Municipality of Prato is a medium sized local administration situated in the centre of Italy (Tuscany) and is one of the LGs involved in the process of testing the new accounting system. The conceptual framework of institutional theories (old institutionalism, new institutionalism and archetype theory) has been applied to describe the process of adoption of the new accounting system.

According to the theoretical model developed by the institutional theories (Covaleski and Dirsmith, 1988; Powell and DiMaggio, 1991) the implementation of the accounting reforms is connected to external stimuli that are exercised on an organization and by the capability to interpret and implement the principles and requirements included in reforms. However, the presence of

* Corresponding author: matteo.pozzoli@uniparthenope.it 
different responses to the same external stimuli suggests (Greenwood and Hinings, 1996; Ezzamel et al., 2012; Liguori and Steccolini, 2012) the existence of internal micro-dynamics which can also explain the response of the organization.

In accordance with the literature, the paper describes the process of implementation of the reform carried out by the Municipality of Prato, assessing the external and internal elements that have influenced the implementation.

The paper is structured in six sections. The second section, following this introduction, includes a review of the research of institutional studies; the literature review allows the identification of the elements that will be described in the analysis of the case study. The third section describes the contents of the reform for the Italian LGs. The fourth section describes the applied methodology. The case of the Municipality of Prato and the process of implementing the reform is described in the fifth section. The final section shows the results of the analysis of the case study, identifying limits to research and proposals for further research.

\section{Literature Review}

Accounting reforms are one of the most widely discussed NPM phenomena under the name of New Public Financial Management (NPFM) (Guthrie et al., 1999). The literature demonstrates that there is no indication of a diminishing interest in this field of research (Hyndman and Connolly, 2011; Lapsley et al., 2009; Paulsson, 2006; Pollanen and Loiselle-Lapointe, 2012).

A considerable part of the literature has dealt with the question of how and why accounting has developed over time and inside specific organizational contexts.(e.g. Libby and Waterhouse, 1996; Burns and Scapens, 2000; Townleyet al., 2003; Covaleski et al., 2003; Ezzamel et al., 2007).

And as already known, the literature regarding the NPM and public accounting generally explains change as something deriving from external sources (Dent et al., 2004; Erakovic and Wilson, 2005; Hammerschmid and Meyer, 2005). Early research has evidence that organizations manifest different responses in the presence of similar contexts.
Substantially, there are three main approaches to analyse the process of accounting change in the public sector: the old institutionalism, the new institutional theory and the archetype theory.

The paper applies the above mentioned approaches to evaluate the external pressures, the institutional adoption of the new requirements and the internal micro dynamics governing the change.

\subsection{The Neo-Institutional Theoretical Frame- work}

The ideas of new institutionalism, also referred to as neo-institutional theory, has been propagated by Meyer and Rowan (1977) and DiMaggio and Powell (1983). The new institutionalism mostly searches for explanations on how the environmental forces may mold and influence organizations. (Meyer and Rowan, 1977; Scott, 2001; Powell and DiMaggio, 1991).In this perspective, new institutionalists often consider the institutionalization and the diffusion of accounting change as exogenously driven as well as resulting from new regulation, cosmetic behaviours or social and technical influences. (Covaleski et al., 2003; Tsamenyi et al., 2006; Ezzamel et al., 2007; AlOmiri and Drury, 2007; Lukka, 2007).Therefore, they mainly focus on understanding the capability of an organization in changing itself by observing how its available choice-set is affected by institutionalized requirements and values(Scott, 2001; Powell and DiMaggio, 1991; Collier, 2001; Lukka, 2007). The literature regarding these issues focuses on the influence elements such as culture, environment and technique have on new practice adoption. (Dillard et al., 2004)Similarly, most of the studies merely address the process of institutional diffusion itself or the socio-economic context leading to its change

The underlying idea of new institutionalism is anchored on two main issues, isomorphism and decoupling.

The isomorphism (DiMaggio and Powell, 1983) is defined as a process through which organizations attempt to adopt similar socially accredited requirements, practices, and structures from their operating environment. Central to isomorphism is the notion of legitimacy, which enforce organizations to comply with external requirements regardless of the appropriateness of these requisites in their specific setting (Ball and Craig, 2010; 
Carpenter and Feroz, 2001; Palmer, Jennings, and Zhou, 1993). Since organizational activities are strongly motivated by legitimacy-seeking behaviour (Dillard, Rigsby, and Goodman, 2004), the search for legitimacy has often proved to be more important than the rational decisions-making the processes themselves (Connolly, Reeves, and Wall, 2009). Meyer and Rowan (1977) argue that, by promoting legitimacy, institutional isomorphism increases the success and survival of organizations.

\section{Table 1}

Mechanisms that transport legitimated requirements and practices to organization

\begin{tabular}{|c|c|c|}
\hline \multicolumn{2}{|c|}{ Mechanism Description } & \multirow{2}{*}{$\begin{array}{l}\text { Researches } \\
\text { Carpenter } \\
\text { and Feroz, } \\
\text { 2001; } \\
\text { Connolly } \\
\text { et al., } 2009\end{array}$} \\
\hline Coercive & $\begin{array}{l}\text { Consists of both the formal } \\
\text { pressure imposed through } \\
\text { legislation and the informal } \\
\text { pressure exerted by those upon } \\
\text { whom the organization is } \\
\text { dependent for resources }\end{array}$ & \\
\hline Mimetic & $\begin{array}{l}\text { Resulting from uncertainties, it } \\
\text { leads organizations to adhere to } \\
\text { the path undertaken by similar } \\
\text { organizations that are regarded as } \\
\text { successful }\end{array}$ & $\begin{array}{l}\text { Covaleski } \\
\text { and } \\
\text { Dirsmith, } \\
1988\end{array}$ \\
\hline Normative & $\begin{array}{l}\text { The organizations endeavor to } \\
\text { adopt the systems, practices, and } \\
\text { procedures widely propagated by } \\
\text { professional bodies. This also } \\
\text { means that normative pressure is } \\
\text { linked to professionalization }\end{array}$ & $\begin{array}{l}\text { Carpenter } \\
\text { and Feroz, } \\
2001 \text {; } \\
\text { Di Maggio } \\
\text { and Powell, } \\
1983\end{array}$ \\
\hline
\end{tabular}

DiMaggio and Powell (1983) state that legitimated requirements and practices are transported to organizations through coercive, mimetic, and normative mechanisms (see Table 3 ).

Another essential part of the neo-institutional based studies is their attempt to demonstrate how the legitimized structures and practices transferred through one or more of the isomorphic mechanisms have decoupled in actual organizational practices (Tsamenyi et al. 2006).

Studies have demonstrated how organizations have used accounting technologies to appear legitimate and how these accounting technologies have remained a ceremonial tool or a product of social rationalization (How and Alawattage, 2012; Ball and Craig, 2010; Rahaman et al., 2004; Siti-Nabiha and Scapens, 2005; Oliver, 1991).

\subsection{The Old Institutional Economics}

Old institutional econonmics studies the rules and routines which affect the processes of change, (Burns and Scapens, 2000; Burns and Baldvinsdottir 2005) focusing particularly on the processes of institutionalization through which the accounting change develops.(Scapens, 1994; Burns et al., 1999; Burns and Scapens, 2000; Brignall and Modell, 2000).

Otherwise, Burns and Scapens (2000), and the old institutional school are concerned with the unfolding of accounting change processes within organizations, mostly regarding the institutionalization of already set accounting practices and actions developing into new ones which are both taken for granted and able to interact with the institutional realm. This is made possible through a process of institutionalization and deinstitutionalization, encoding and decoding.

\subsection{The Archetype Theory}

In recent years, indeed, more studies have delineated the limitations of new institutionalism in explaining the processes whereby institutionalized ideas and practices are established, disseminated, and decomposed at intra-organizational levels (Dillard et al., 2004; Ezzamel et al., 2007; Liguori and Steccolini, 2012).

The archetype theory (Hinings and Greenwood, 1988; Greenwood and Hinings, 1996) states that organizations filter environmental pressures by going through an internal process of interpretation and attribution of meanings. In more recent literature (Conrad and Uslu, 2012; Dillard et al., 2004; Irvine, 2011) it has therefore been argued that, despite confronting similar external environmental pressures, organizations respond differently, leading to different outcomes of the proposed changes (Ezzamel, Robson, and Stapleton, 2012; Liguori and Steccolini, 2012). The archetype framework allows distinguishing between different outcomes (radical vs. incremental), paces (i.e. evolutionary versus revolutionary) and levels (structures and systems versus ideas and values) of change, adopting a micro-level perspective (the organization). 


\section{Table 2}

Elements to evaluate the degree of consistency of change in the existing archetype

\begin{tabular}{ll}
\hline Elements & Definition \\
\hline Outcomes & $\begin{array}{l}\text { radical change when it refers also to the } \\
\text { related interpretive schemes } \\
\text { incremental change happens when only the } \\
\text { structures and the systems change }\end{array}$ \\
Pace & evolutionary change, when it occurs slowly and \\
& gradually \\
& revolutionary change, when it happens swiftly \\
& and affects virtually all parts of the organization \\
& simultaneously \\
the change can involve the structure and & system of the organization \\
& the change can involve the ideas and values of \\
& the organization
\end{tabular}

Archetype theory considers changes in structures and systems within already institutionalized archetypes. It then allows focusing on how changes in structures and systems can lead to a change in ideas as well.

Archetype theory provides a comprehensive framework considering both external pressures and intraorganizational dynamics. An archetype may be, in fact, defined as a set of structures and systems that mirrors a single interpretive scheme, consisting of ideas, beliefs and values (Greenwood and Hinings, 1996).

According to the archetype theory, for which each archetype stands for a way of acting and as an example of rationalized myth, both market and institutional forces are two of the environmental factors which affect change (Meyer and Rowan, 1977; Greenwood and Hinings, 2006).

Specifically market factors include demand, geographic distance, size, service and product mix relative to competitors, (D'Aunno et al., 2000) while institutional factors consist of regulations, requirements and cognitive models that influence organizational behaviours.(Scott, 2001).

Anyway, change is not only influenced by external pressures, (Hinings and Greenwood, 1988; TerBogt and Van Helden, 2000) but also by intra- organizational conditions (Pettigrew, 1985) or external factors acting as constraints and stimuli which responses to and are processed by the members of an organization.

Table 3

Factors affecting the transition projects

\begin{tabular}{|c|c|c|}
\hline Factor & Definition & Research \\
\hline Interest & $\begin{array}{l}\text { Interest of those effected } \\
\text { by change }\end{array}$ & (Lukes, 1974); \\
\hline Values & $\begin{array}{l}\text { Conceptions of what an } \\
\text { organization should be } \\
\text { doing, of how it should be } \\
\text { doing it and of how it } \\
\text { should be judged }\end{array}$ & $\begin{array}{l}\text { Hinings and } \\
\text { Greenwood, 1988; } \\
\text { Greenwood and } \\
\text { Hinings, } 1996\end{array}$ \\
\hline $\begin{array}{l}\text { Power of } \\
\text { group }\end{array}$ & $\begin{array}{l}\text { The power of groups to } \\
\text { influence the translation of } \\
\text { their values and their } \\
\text { interests into favourable } \\
\text { organizational } \\
\text { arrangements }\end{array}$ & $\begin{array}{l}\text { Pfeffer, 1981; Hickson } \\
\text { et al., } 1986\end{array}$ \\
\hline $\begin{array}{l}\text { Capacity } \\
\text { for action }\end{array}$ & $\begin{array}{l}\text { The capacity for action is } \\
\text { determined by a } \\
\text { combination of technical } \\
\text { (clear understanding of } \\
\text { the new interpretive } \\
\text { scheme and related } \\
\text { systems and tools, skills } \\
\text { and competencies to } \\
\text { design new organizational } \\
\text { structures and routines) } \\
\text { and managerial } \\
\text { capabilities (leadership, } \\
\text { ability in achieving the } \\
\text { final destination }\end{array}$ & LiguoriSteccolini 2012 \\
\hline
\end{tabular}

\section{The Process of Accounting Reform of LGs}

\subsection{The Scenario}

Since January 2010 the Italian legislation has begun a process of reform of the public administration accounting systems. The law 196/2009 outlined the principles to modify the accounting system of the public administrations at central (the Sate) and local level (the LGs). One of the leading purposes of the law 196/2009 is the harmonisation 
of the accounting systems of the different levels of government and of public expenditures.

The majority of public administrations apply systems of commitment accounting based on modified cash accounting recognitions (the State, the central agencies and the LGs), while a smaller number uses a system of full accrual accounting (in the healthcare and social security).

The accounting system of Municipalities and Districts, at last, is defined by the Decree 267/ 2000.

The research focuses on the description and analysis of the reform of LG accounting system outlined by the Decree 118/2011 (there in after the "decree").

\subsection{The Accounting Reform of the Italian Local Governments}

The procedures for the implementation of the accounting reform of LGs are outlined in the decree (the decree). The provisions of the decree are directed to Regions, Provinces and Municipalities. They are, moreover, applied to instrumental organizations, companies and associations under the direct control of LGs (for example, agencies, companies, foundations, consortia etcetera).

With the decree, the Government pursues the aim of harmonizing the accounting systems of local authorities and their instrumental organizations. To this end, the decree intervenes modifying and harmonising:

a. The informative purposes of the accounting system, introducing, for the Regions, the obligation to apply, in addition to the traditional authorisation model, the accrual basis of accounting. Furthermore, the decree establishes the obligation to prepare consolidated financial statements for local authorities. Finally, the decree provides for the preparation of the cash flows statement

b. the lay-out of balance sheets and of other financial statements;

c. the content of financial statements and

d. the accounting principles. The decree provides general accounting standards and applied accounting standards; these last ones will be issued in their final version by a subsequent decree that will be definitively approved after an experimentation period of two years

As far as the informative purposes are concerned, the decree revises (introduces for the Regions) the system of accrual based accounting that flanks the commitment accounting based on modified cash accounting.

The purpose of the harmonisation is also pursued through the adoption of the same layout of financial statements and the same dates of approval.

The decree amends the formats of the financial statements and replaces them with standardized statements. In addition, to realise the standardisation of the financial statements, the decree sets the use of a single chart of accounts common to all LGs. The chart of accounts is very detailed and cannot be changed by LGs. However, LGs can only integrate the chart of accounts by increasing the level of detail of the accounts.

\subsection{The Implementation of the Reform and the Two-Years Experimentation Period}

Article 36 of Decree no.118 establishes an experimentation period for the new accounting system of LGs. The expected timing for experimentation is two years from, January 2012 to December 2013. During this period, a limited number of LGs identified among municipalities, provinces and regions will apply the new accounting system. At the end of the experimental period (from January 2014) a corrective decree is scheduled that, following the results of the experimental period, updates the accounting system provided by the decree. After the enactment of the corrective decree, the new accounting rules will apply to all LGs.

With a specific legislative provision, the Government has identified the means of implementation of the experimental period defining: the applied accounting standards; the content of the chart of accounts and the new financial statements.

After the enactment of the decree that regulates the experimental period, the LGs participating in the experimentation have been selected. The selection of LGs has been carried out among the LGs who had applied of their own accord. The choice of LGs has been carried out by the Ministry of Economy and Finance after verifying that the 
sample of LGs was representative of: the different kind of LGs, (that is, the regions, provinces and municipalities); the demographic dimension of LGs (small medium and large organizations) and the different geographical areas of the country (North, Central and South).

In 2012, the first year of experimentation, 85 LGs applied to participate in the experimentation. They are respectively: 5 regions, 12 provinces and 68 municipalities.

After the start of the experimentation period some LGs expressed their intention to leave while others were excluded because they never began experimenting with the new accounting system.

At the end of the first year, twenty LGs had abandoned the experimentation, namely: 1 Region has suspended the experimentation, 13 municipalities have refused to continue in 2013 and six municipalities were excluded because they never began experimenting.

At the same time, one LG has applied to participate in the experimentation starting from the year 2013 . In 2013 the LGs involved in the experimentation are 66, divided into 4 regions, 12 provinces and 50 municipalities.

In the first year of experimentation, the LGs applied only some of the provisions of the decree. In 2012, the authorities adopted: the new layout of the financial statements (budget and reporting), the integrated chart of accounts and the new modified cash basis accounting standard.

In addition, in the first year of experimentation, the LGs have used the previous financial statements for the management of the LG. The new financial statements have been flanked to the previous schemes for just cognitive purposes.

Finally, the decree on experimentation has planned to establish a technical committee (composed of: experienced technicians of the Ministry, representatives of Istat, representatives of the accounting professions, representatives of banks association (ABI) and representatives of LGs involved in the experimentation) to support the LGs who experiment the new accounting system.

The institution of the "Budgets Group" is a novelty for the process of reform of the public administration in Italy, as it involves the representatives of local authorities to state the accounting rules that they have to apply and as it involves the representatives of the accounting professions in the definition of the accounting standards and the financial statements of the public administrations.

\section{Research Method}

This paper applies the case method (Eisenehardt, 1989; Eisenhardt and Graebner, 2007). It is generally accepted that the case study approach is an effective method to discover new information on a specific issue, irrespective of the discipline it is referred to (Geels, 2002). According to Yin (2009), the methodology of case study is used to describe the cause and the development of contemporary events and to analyse its behavioural dimension. Specifically Yin defines the "case study method" as follows:

"An empirical inquiry about a contemporary phenomenon (for example, a "case"), set within its real world context -especially when the boundaries between phenomenon and context are not clearly evident (Yin, 2009, p.18)".

The case presents, in more detail, the features of the exploratory case study as it: (a) pertains to a complex phenomenon; (b) assumes the absence of the control of the investigation upon the phenomena; (c) incorporates a multitude of data to acquire and corroborate the provided observations; (d) relies upon qualitative data; (e) aims at providing a detailed portrait of the phenomenon in relation to the factors abstractly observed (Ogawa and Malen, 1991). From this point of view, the case study is a starting step towards further analyses.

The above described methodology refers to the empirical analysis of the case of Prato through the instruments of the case analysis.

The study includes semi-structured interviews with the manager of the project at the Municipality of Prato and the other people involved in the transition process. The form of semi-structured interviews has been chosen as it has been considered as the best form of representation for a single case research (Drever, 1995). Specifically, the adoption of the case study has been conducted in order to test whether the mentioned literature concerning the criticalities encountered in imple- 
menting accounting reforms can be confirmed. The interviews were oriented to:

a. describe the process leading to the implementation of the new requirements;

b. comprehend the level of the involvement;

c. illustrate the occurred criticalities;

d. identify the potential solutions to the existing issues.

The case study approach followed in this research has been affected in the following steps:

- the first step has regarded the preparation of the questionnaire starting from the main criticalities identified by the literature in relation to the adoption of the accounting reform from a reporting and management point of view;

- the second step concerned the analysis of the empirical evidence arising from this research and the information arising from the interview;

- the third and last step has addressed the question whether these considerations are generally applicable to the whole set of municipalities or are specific to this case study.

The research question wonders how the proposed general requirements are going to be applied.

\section{The Description of the Research: The Case of the Municipality of Prato}

\subsection{The Municipality of Prato and the Choice to Participate in the Experimentation}

Prato is a city of about 190,000 inhabitants, which is geographically situated in the centre of Italy (in Tuscany). As it will arise in the course of the interview, the Municipality of Prato has got a high level in accounting competence.

The decision to participate in the experimentation of the new accounting system has been assumed by the Mayor in accordance with the chief finance department (CFO). Specifically, when (September of 2011) the regional organization representing LGs (ANCI Toscana) advanced the proposal of involving the Municipality of Prato in the experimentation, the Mayor asked the CFO for the decision concerning the participation in the project.
The decision to participate in the experimentation was made without particular normative pressures. In fact, there was not any pressure from the Ministry or Central Agencies. Also the economic incentives for participation were not influential, because they were unknown at the time of the decision.

The conclusion to be part of the experimentation was (i) "emotionally" made by the finance department and (ii) related to the potential advantages embodied in the adoption of the Decree $118 / 2011$.

The chance to attend the task force "Budget Group" acted as a stimulus to affect the decision process was a facilitating feature.

The internal and behavioural pressures rather than the external pressures arising from normative and market pressures had the most relevant impact in the decision to participate in the experimentation.

\subsection{The Process of Adopting the New Accounting System}

After having chosen to participate in the experimentation, a short training course (four hours) was organized to inform the staff about the main features of the new accounting system.

The first phase in the implementation of the accounting system was to codify the current accounts into the "new" accounts. The statements' items were codified, moving from the current chart of account to the new integrated chart of accounts, with the purpose of recognizing the items belonging to both models.

The current accounts (and consequently, the financial statements) have been re-classified into the new budget formats organized by missions and programs.

This step was made to prepare the 2012 budget in the current format for the Council's approval, while the new format was used only to inform the Council.

It was only in 2013 that the new modified cash basis of accounting has been applied in the day-byday operations as well. The new accounting standard changes were made to the accounting software and were adapted exclusively to the procedures which were not consistent with the new 
accounting system (for example, the process of payment).

Moreover, to communicate the adjustments in the procedures and internal routines, the finance department prepared two internal directives. The members of the finance department had some informal conversations with the other offices involved; they discussed how to apply the new accounting standards. The changes of the LG's procedures have been light and were aimed at updating the previous model to the technical adoption of the new requirements; there were no changes in the organizational structure. Only the Accounting Regulation (AR) has been changed; it could have been changed at the end of the experimentation, but the LG decided to modify the AR, because the decree 174/2012 -providing new rules on LGs' internal controls- required a modification of the AR. In this context, it was decided to propose new changes embodying the requirements arising from the experimentation.

The CFO states: "There are more things to do than things being done. The most challenging part is the re-measurement of the unpaid commitments (residuipassivi) and uncollected revenue (residuiattivi). Now, it is time to adjust the management model and to allocate the future receipts and disbursements based on the new model'. Furthermore, the standards of accrual basis of accounting and consolidated financial statements are unapplied at the moment.

The first phase of the implementation of the reform has been carried out by the adaptation of the previous accounting system to the new one. The changes were not radical and only marginally affected the accounting systems and procedures of the LG. In the first year of the experimentation, the change can be described as evolutionary and incremental. It also suggests that, in the process of legitimization, the LG used accounting technologies to appear legitimate (decoupling) and explains how these accounting technologies could remain a ceremonial tool or a product of social rationalization.

\subsection{Internal Dynamics and Implementation of New Accounting Rules}

The process of change in the accounting system has been promoted and supported by the finance department staff ( 8 employees) under the direction of the CFO.

The interview has revealed some resistances in implementing the new accounting system.

The implementation of the change in the accounting system has been addressed mainly from the perspective of technical changes and does not affect the values and ideas with which the LG is managed. In fact, there have been only informal meetings on specific issues and individual adjustments of the software and procedures. No meeting was made to inform the staff about the values and the purposes of new accounting system or to explain the reasons for which the LG decided to participate in the experimentation. The main focus was on technical aspects.

Currently, the political component of the LG cannot fully appreciate the purpose of the reform, because the changes are not completely applied.

The promoter of accounting change (the CFO) states: "It is difficult to explain to politicians the reason for which the budget under the new rules had such a high financial surplus. A high financial surplus can be considered as an indicator of inefficiency in the use of financial resources. In this case, it is important to fully explain that the financial surplus results from the application of new accounting standards and from the combined reduction of unpaid commitments (residuipassivi) and uncollected revenue (residuiattivi). From this perspective, I think it could be useful to prepare a technical report in which we determine the financial surplus applying the old accounting standards, in order to allow the political management to express a judgment on the City's management, irrespective from the mentioned accounting changes". Also in this case, the way in which the effect of the reform is explained, is treated with a technical approach.

The way in which the change has been managed (technical approach) is the reason that led to an evolutionary and gradual change. In fact, the change involves exclusively the technical infrastructure and not the system of ideas and values of the $\mathrm{LG}$. 


\section{Conclusions and Future Research}

This research is characterised by studying the implementation process of a reform and not its results. The analysis has been conducted under the framework of the institutional and archetype theories that identify the element which leads the change in the interaction between external pressures and internal factors. The institutional theories affirm that the external pressures determine the response of the organization.

The change in an accounting system can be analysed by the change in procedures and routines of the organization through a process of institutionalisation and deinstitutionalisation (old institutional theory).

The change in accounting system can be also analysed by expressing a judgment on the nature of the external pressures (cultural, environmental and technical) and the mechanisms (coercive, mimetic, and normative) to react to the external pressures in order to obtain the legitimacy of the organization (new institutional theory).

According to the archetype theory, the outcome of change in an accounting system is affected by the internal dynamic and by the process of interpretation and attribution of meanings of the process of accounting reform. For this purpose, the research analyses the external pressure and the internal dynamic in the process of implementation of the new accounting system, proposed by the Decree $118 / 2011$.

The research question wonders how the proposed requirements are going to be applied. To respond to this question, the process of implementation has been analysed in terms of external stimuli and internal dynamic of implementation.

The study of the case shows that the decision to participate in the experimentation was taken without particular external pressures. In fact the Municipality of Prato decided to candidate itself to the experimental period. The greatest impact has been produced by internal and behavioural pressures rather than external pressures arising from normative and market pressures (Liguori, 2012). The decision was (a) "emotionally" made by the finance department and (b) related to the potential advantages embodied in the adoption of the Decree 118/2011. The chance to attend the task force "Budget Group" was also a stimulus to participate in this project.

In terms of the process of implementation of the new accounting system, the first year of the implementation was carried out by the adaptation of the previous accounting system to the new one. The changes were not radical and only marginally affected the accounting system and procedures of the LG (DiMaggio and Powell, 1983). The changes of the LG's procedures were moderate and aimed at updating the previous model to the technical adoption of the new requirements. There was no change in the organizational structure. In terms of pace the change can be described as evolutionary and incremental (Carpenter and Feroz, 2001). It also suggests that in the process of legitimisation the LGs have used accounting technologies to appear legitimate (decoupling)and the new rules "can be useful in promoting a cosmetic change" rather than an archetypal change (Liguoriand Steccolini, 2012).

As far as internal dynamics are concerned, the process of change has been promoted and supported by the staff of the finance department and by the direction of the CFO. As observed above, the implementation of the change in accounting systems has mainly interested the technical changes and did not affect the values and ideas with which the LG is managed. The way in which the change has been managed (technical approach) is the reason that led to an evolutionary and gradual change.

When looking at the outcome, as far as technical aspects are concerned, it should be noted that, as it can be inferred from the interview, the reform uses the accounting instruments to affect the LGs' managerial system. Starting from this consideration, the legislation is trying to find some converging recognition criteria (for example, in regards to non-exchange transactions) for the accrual and the cash bases of accounting.

The modifications to the current requirements are finalised to achieve specific results and do not follow any leitmotif (Burns Scapens, 2000). Specifically, the experimentation does not seem to move towards the International Public Sector Accounting Standards Board's (IPSASB) requirements, even if there are significant examples (for example, substance over form, leases), whereas the convergence trend towards International Public 
Sector Accounting Standards (IPSASs) would appear to be pursued.

The conclusion is that the reform seems to be -and contextually is perceived as- a technical proposal aimed at modifying some significant current aspects, which may lead to inappropriate resource management.

This research presents some undoubted limitations. It is mainly focused upon the accounting features, considering the data process (Hopwood, 1987) rather than the financial statements outcome. That being said, it is clear that public sector accounting reform involves other crucial managerial and organizational features which should be analysed more in depth in order to have an exhaustive framework of the reform.

Another evident limit of this paper concerns the fact that Prato represents a single case, whose analysis identifies a qualitative analysis; its model

\section{References}

Adhijari P. Kuruppu C. Matilal S. (2013), "Dissemination and institutionalisation of public sector accounting reforms in less developed countries: a comparative study of Nepalese and Sri Lankan central governments", Accounting Forum, Available at: http://dx.doi.org/ 10.1016/j.accfor.2013.01.001

Al-Omiri, M. and Drury, C. (2007), “A survey of factors influencing the choice of product costing systems in UK organizations", Management Accounting Research, Vol. 18 No. 4, pp. 399-424

Alvesson, M. (2003), "Beyond neoposotivists, romance, and localists: A reflexive approach to interviews in organizational research", Academy of Management Review, Vol. 28 No. 1, pp. 13-33

Ball, A., and Craig, R. (2010), "Using neoinstitutionalism to advance social and environmental accounting?", Critical Perspectives on Accounting, Vol. 21 No. 4, pp. 283293

Benito, B., Brusca, I., and Montesinos, V. (2007), "The harmonisation of government financial information systems. The role of the IPSASs", may not be reproduced or valid for other similar municipalities.

Campbell (1975) affirms that "...in a single qualitative case study, the conscientious social scientist often finds no explanation that seems satisfactory." In this context, the paper outlines that this study represents an explanatory case, finalised to take a picture of the application phase more than an investigation of the results of the reform. However, an examination of multiple cases, representing different geographical, dimensional and organizational contexts, could provide a more exhaustive picture of this investigation.

Lastly, this analysis should be repeated after the experimentation, in order to comprehend if the feeling presented in the experimentation phase is confirmed even once this transitory period is expired.

International Review of Administrative Sciences, Vol. 73 No. 2, pp. 293-317

Berg, B. (2009), Qualitative research method (7th ed.), Pearson Boston

Brignall, S. and Modell, S. (2000), "An institutional perspective on performance measurement and management in the "new public sector", Management Accounting Research, Vol. 11, pp. 281-306

Burns, J. and Scapens, R.W. (2000), "Conceptualizing management accounting change: an institutional framework", Management Accounting Research, Vol. 11 No. 3

Burns, J., Ezzamel, M. and Scapens, R. (1999), "Management accounting change in the UK", Management Accounting, Vol. 77 No. 3, pp. 28-30

Campbell, D. T. (1975), "Degrees of freedom and the case study", Comparative Political Studies, Vol. 8, pp. 178-193

Carpenter, V., and Feroz, E. (2001), "Institutional theory and accounting rule choice: An analysis of four US state governments' decisions to adopt generally accepted accounting princi- 
ples", Accounting, Organizations and Society, Vol. 26 No. 7-8, pp. 565-596

Connolly, C., Reeves, E., and Wall, A. (2009), "Isomorphism: An explanation for the popularity of public-private partnerships?", The Irish Accounting Review, Vol. 16 No. 1, pp. 119

Conrad, L., and Uslu, P. (2012), "UK heath sector performance management: Conflict, crisis and unintended consequences", Accounting Forum, Vol. 36 No. 4, pp. 231-250

Covaleski, M. A., and Dirsmith, M. W. (1988), "An institutional perspective on the rise, social transformation, and fall of a university budget category", Administrative Science Quarterly, Vol. 33 No. 4, pp. 562-587

Covaleski, M.A., Dirsmith, M.W. and Samuel, S. (2003), "Changes in the institutional environment and the institutions of governance: extending the contributions of transaction cost economics within the management control literature", Accounting, Organizations and Society, Vol. 28, pp. 417-41

D’Aunno, T., Succi, M., Jeffrey, A. and Alexander, J.A. (2000), "The role of institutional and market forces in divergent organizational change - statistical data included", Administrative Science Quarterly, Vol. 45 No. 4, pp. 679-703

Dent, M., Howorth, C., Mueller, F. and Preuschoft, C. (2004), "Archetype transition in the German Health Service? The attempted modernization of hospitals in a North German state", Public Administration, Vol. 82 No. 3, pp. 727-42

Dillard, J.F., Rigsby, J.T. and Goodman, C. (2004), "The making and remaking of organizational context", Accounting, Auditing \& Accountability Journal, Vol. 17 No. 4, pp. 506-42

DiMaggio, P. J., and Powell, W. W. (1983), “The iron cage revisited: Institutional isomorphism and collective rationality in organizational fields", American Sociological Review, Vol. 48 No. 2, pp. 147-160

Drever E. (1995), "Using Semi-Structured Interviews in Small-Scale Research. A Teacher's Guide", Scottish Council for Research in Education, Edinburgh
Eisenhardt, K.M. (1989), "Building theories from case study research", Academy of Management Review, Vol. 14 No. 4, pp. 532-50

Eisenhardt, K.M., Graebner M.E. (2007), “Theory building from cases: opportunities and challenges", Academy of Management Journal, Vol. 50 No. 1, pp. 25-32

Erakovic L. and Wilson M. (2005), "Conditions of Radical Transformation in State-Owned Enterprises", British Journal of Management, Vol. 16 No. 4, pp. 193-313

Ezzamel, M., Hyndman, N., Johnsen, A., Lapsley, I., and Pallot, J. (2007), "Experiencing institutionalisation: The development of new budgets in the UK devolved bodies", Accounting, Auditing \& Accountability Journal, Vol. 20 No. 1, pp. 11-40

Ezzamel, M., Robson, K., and Stapleton, P. (2012), "The logic of budgeting: Theorization and practice variation in the educational field", Accounting Organizations and Society, Vol. 37 No. 5, pp. 281-303

Ezzamel, M., Robson, K., Stapleton, P. and McLeanb, C. (2007), "Discourse and institutional change: giving accounts and accountability", Management Accounting Research, Vol. 18, pp. 150-71

Frankfort-Nachmias, C., and Nachmias, D. (2008), Research methods in the social sciences (7th ed.). USA: Worth Publishers

Frumkin, P., and Galaskiewicz, J. (2004), "Institutional isomorphism and public sector organizations", Journal of Public Administration Research and Theory, Vol. 14 No. 3, pp. 283-307

Geels, F.W., (2002), “Technological transitions as evolutionary reconfiguration processes: a multilevel perspective and a case-study", Research Policy, Vol. 31 No. 8/9, pp. 1257-1274

Greenwood, R. and Hinings, C.R. (1996), "Understanding radical organizational change: bringing together the old and the new institutionalism", Academy of Management Review, Vol. 21 No. 4, pp. 1022-54

Greenwood, R. and Hinings, C.R. (2006), "Radical organizational change", in Clegg, S., Hardy, S. and Nord, W. (Ed.), The Sage Handbook of 
Organization Studies, Sage Publications, Thousand Oaks, CA.

Guthrie, G. (1998), “Application of accrual accounting in the Australian public sector Rhetoric or reality", Financial Accountability \& Management, Vol. 14 No. 1, pp. 1-19

Guthrie, J., Olson, O., and Humphrey, C. (1999), "Debating developments in new public financial management: The limits of global theorising and some new ways forward", Financial Accountability \& Management, Vol. 15 No. 3-4, pp. 209-228

Hammerschmid, G. and Meyer, R. (2005), "New public management in Austria: local variation on a global theme?", Public Administration, Vol. 83 No. 3, pp. 709-33

Hinings, C.R. and Greenwood, R. (1988), The Dynamics of Strategic Change, Basil Blackwell, Oxford

Hopwood (1987), "The archaeology of accounting systems", Accounting, Organizations and Society, Vol. 12 No. 3, pp. 207-234

How, S., and Alawattage, C. (2012), "Accounting decoupled: A case study of accounting regime change in Malaysian Company", Critical Perspectives on Accounting, Vol. 23 No. 6, pp. 403-419

Hyndman, N., and Connolly, C. (2011), “Accruals accounting in the public sector: A road not always taken", Management Accounting Research, Vol. 22 No. 1, pp. 36-45

Irvine, H. (2011), "From go to woe: How a not-forprofit managed the change to accrual accounting", Accounting, Auditing \& Accountability Journal, Vol. 24 No. 7, pp. 824-847

Jones R. and Pendelbury M. (2000), Public Sector Accounting, $5^{\text {th }}$ edition, Pearson Education Limited, Essex

Lapsley I, Mussari R., and Paulsson G, (2009), "On the Adoption of Accrual Accounting in the Public Sector: A Self-Evident and Problematic Reform", European Accounting Review, Vol. 18, No. 4, 2009, pp. 719-723

Libby, T. and Waterhouse, J.H. (1996), "Predicting change in management accounting systems",
Journal of Management Accounting Research, Vol. 8, pp. 137-50

Liguori, M. (2012), "Radical Change, Accounting and Public Sector Reforms: A Comparison of Italian and Canadian Municipalities", Financial Accountability \& Management, Vol. 28 No. 4, pp. 437-463

Liguori, M., and Steccolini, I. (2012), “Accounting change: Explaining the outcomes, interpreting the process", Accounting, Auditing \& Accountability Journal, Vol. 25 No. 1, pp. 27-70

Lukka, K. (2007), "Management accounting change and stability: loosely coupled rules and routines in action", Management Accounting Research, Vol. 18, pp. 76-101

Meyer, J., and Rowan, B. (1977), "Institutional organizations: Formal structures as myth and ceremony", American Journal of Sociology, Vol. 83 No. 2, pp. 340-363

Mussari, R. (1994), Il management delle aziende pubbliche - profili teorici, CEDAM, Padova

Mussari, R. (1997), "Autonomy, responsibility and new public management", in Jones, L.R. and Schedler, K. (Ed.), International Perspectives on the New Public Management, JAI Press, London.

Ogawa R. T., Malen B. (1991), “Towards Rigor in reviews of Multivocal Literatures: Applying the Exploratory Case Study Method", Review of Educational Research, 61 No. 3, pp. 265-286

Oliver, C. (1991), "Strategic responses to institutional processes", The Academy of Management Review, Vol. 16 No. 1, pp. 145-79

Palmer, D. A., Jennings, P. D., and Zhou, X. (1993), "Late adoption of the multidivisional form by large US corporations: Institutional, political and economic accounts", Administrative Science Quarterly, Vol. 38 No. 1, pp. 100-131

Paulsson, G. (2006), "Accrual accounting in the public sector: Experiences from the central government in Sweden", Financial Accountability \& Management, Vol. 22 No. 1, pp. 4762. 
Pettigrew, A.M. (1985), The Awakening Giant: Continuity and Change in ICI, Basil Blackwell, Oxford

Pilcher R., Dean G. (2009), "Implementing IFRS in local government: value adding or additional pain?", Qualitative Research in Accounting \& Management, Vol. 6 No. 3, pp. 180-196

Pina, V., Torres, L., and Yetano, A. (2009), "Accrual accounting in EU local governments: One method, several approaches", European Accounting Review, Vol. 18 No. 4, pp. 765-807

Pollanen, R., and Loiselle-Lapointe, K. (2012), "Accounting reform in the government of Canada: Exploratory evidence on accrual accounting adoption and impact", Financial Accountability \& Management, Vol. 28 No. 4, pp. 359-377

Powell, W. and DiMaggio, P.J. (1991), The New Institutionalism in Organizational Analysis, The University of Chicago Press, Chicago, IL

Pozzoli M. (2005), Principi contabili ed enti locali. La prospettiva internazionale, Franco Angeli, Milano

Pozzoli M. (2012), "I principi contabili per gli enti locali”, in Mulazzani, M (Ed.) La revisione degli enti locali, Maggioli, Rimini, pp. 313-322

Qu, S., and Dumay, J. (2011), "The qualitative research interview", Qualitative Research in Accounting \& Management, Vol. 8 No. 3, pp. 238-264

Rahaman, A. S., Lawrence, S., and Roper, J. (2004), "Social and environmental reporting at the VRA: Institutionalised legitimacy or legitimation crisis?", Critical Perspectives on Accounting, Vol. 15 No. 1, pp. 35-56

Ranucci S. (2012), "Il processo di armonizzazione contabile degli enti territoriali: il D.Lgs. n. 118/2011 e l'avvio della sperimentazione", Azienditalia, Vol. 1, pp. 5-10

Ribeiro, J.A. and Scapens, R.W. (2006), "Institutional theories in management accounting change", Qualitative Research in
Accounting and Management, Vol. 3 No. 2, pp. 91-111

Scapens, R.W. (1994), "Never mind the gap: towards an institutional perspective on management accounting practice", Management Accounting Research, Vol. 5, pp. 301-21

Scott, W.R. (2001), Institutions and Organizations, Sage Publications, London

Silverman, D (2007), Interpreting qualitative data (3rd ed.). London: Sage

Silverman, D (2010), Doing qualitative research (3rd ed.). London: Sage

Siti-Nabiha, A. K., and Scapens, R. W. (2005), "Stability and change: An institutional study of management accounting change", Accounting, Auditing \& Accountability Journal, Vol. 18 No. 1, pp. 44-73

Stake, R. (2000), "Case studies", in Denzin N., and Lincoln Y (Ed), Handbook of qualitative research (2nd ed., 435-454), Thousand Oaks, CA: Sage

Ter Bogt, H. and Van Helden, G.J. (2000), "Accounting change in Dutch government: exploring the gap between expectations and realizations", Management Accounting Research, Vol. 11, pp. 263-79

Townley, B., Cooper, D.J. and Oaks, L.S. (2003), "Performance measures and the rationalization of organizations", Organization Studies, Vol. 24 No. 7, pp. 1045-71

Tsamenyi, M., Cullena, J. and Gonza'lez, J.M. (2006), "Changes in accounting and financial information system in a Spanish electricity company: a new institutional theory analysis", Management Accounting Research, Vol. 17 No. 4, pp. 409-32

Yin R. K. (2009), Case Study Research Design and Methods (IVth ed), SAGE Publications, Thousand Oaks

Zucker L.G. (1987), "Institutional theories of organization", Annual Review of Sociology, Vol. 13, pp. $443-464$ 


\section{Appendix 1}

The semi-structured interview

\begin{tabular}{|c|c|c|c|c|}
\hline \multirow{2}{*}{$\begin{array}{l}\text { A External Stimuli } \\
1 \text { Juridical Pression } \\
\text { DiMaggio and } \\
\text { Powell, } 1983\end{array}$} & \multicolumn{2}{|c|}{ Question } & \multicolumn{2}{|c|}{ Answer } \\
\hline & 1. & $\begin{array}{l}\text { What is the reason that has led to the } \\
\text { experimentation? }\end{array}$ & & \\
\hline & 1.1 & $\begin{array}{l}\text { What were the promoters and the } \\
\text { facilitators? (Carpenter and Feroz, 2001; } \\
\text { Connolly et al., 2009) }\end{array}$ & 1.1 & $\begin{array}{l}\text { The regional organization representing LGs } \\
\text { (ANCI Toscana) advanced the proposal. The } \\
\text { Mayor asked the chief finance department } \\
\text { (CFO) for the decision concerning the } \\
\text { participation in the project. }\end{array}$ \\
\hline & 1.2 & $\begin{array}{l}\text { What were the reasons that led to the } \\
\text { experimentation? (DiMaggio and Powell, } \\
1983 \text { and Connolly et al., 2009) }\end{array}$ & 1.2 & $\begin{array}{l}\text { The decision to be part of the } \\
\text { experimentation was (i) "emotionally" made } \\
\text { by the finance department"; and (ii) related } \\
\text { to the potential advantages embodied in the } \\
\text { adoption of the Decree 118/2011. }\end{array}$ \\
\hline & 1.3 & $\begin{array}{l}\text { Was the monetary incentive provided from } \\
\text { the experimentation important in the } \\
\text { decision to participate? (DiMaggio and } \\
\text { Powell } 1983 \text { and Connolly et al., 2009) }\end{array}$ & 1.3 & $\begin{array}{l}\text { The monetary incentive was not crucial in } \\
\text { the decision to attend the project. The } \\
\text { decision to participate in the experimentation } \\
\text { (September 2011) was made before the } \\
\text { issuing of the application requirements and } \\
\text { the monetary incentives. }\end{array}$ \\
\hline & 1.4 & $\begin{array}{l}\text { Was the chance to attend the "Budget } \\
\text { Group" task force a facilitating feature? } \\
\text { (Hinings and Greenwood, 1988) }\end{array}$ & 1.4 & $\begin{array}{l}\text { Yes, it was. The chance to attend the task } \\
\text { force as a stimulus to affecting the decision } \\
\text { process was a facilitating feature. }\end{array}$ \\
\hline & 1.5 & $\begin{array}{l}\text { Are there professional relations with anyone } \\
\text { belonging to the accounting standards task } \\
\text { force? If yes, has this circumstance affected } \\
\text { your decision to attend the experimentation? } \\
\text { (Pfeffer, 1981; Hickson et al., 1986) }\end{array}$ & 1.5 & No, there are no relations. \\
\hline \multirow{4}{*}{$\begin{array}{l}2 \text { Market pressure } \\
\text { Greenwood and } \\
\text { Hinings, } 1996\end{array}$} & 2. & $\begin{array}{l}\text { What are, in your opinion, the main } \\
\text { purposes pursued by the Decree } 118 / 2011 \text { ? }\end{array}$ & & \\
\hline & 2.1 & $\begin{array}{l}\text { Could you identify them? (Dillard et al., } \\
\text { 2004) }\end{array}$ & 2.1 & $\begin{array}{l}\text { In my opinion, confirmed by some } \\
\text { conversation with people involved in the } \\
\text { enactment of the decree, the focus is on the } \\
\text { cash flow management. }\end{array}$ \\
\hline & & & & $\begin{array}{l}\text { One of the main purposes pursued by the } \\
\text { reform is to reduce the impact of the unpaid } \\
\text { commitments. }\end{array}$ \\
\hline & & & & $\begin{array}{l}\text { Another important orientation concerns the } \\
\text { different management of the cash inflows. } \\
\text { This feature provides for a robust } \\
\text { involvement of the administrative office in } \\
\text { cash inflows and outflows in compliance with } \\
\text { the decree } 174 / 2012 \text { as well. The re- } \\
\text { measurement of the uncollected revenue is } \\
\text { well described, and this is probably related } \\
\text { to the fact that many LGs have had financial } \\
\text { problems due to this issue. }\end{array}$ \\
\hline
\end{tabular}


3 Cognitive pressure

Scott, 2001
2.2 Can the new accounting requirements impact on the relations between the LG and its main partners (eg, Central State, Ministers, Regions, subsidiaries, community, et cetera)? If yes, with whom and to what extent? (Mizruchi and Fein, 1999 - Greenwood and Hinings, 1996 and Hickson et al., 1986)

1. According to your experience, what are the main issues arising from the management of a LG? (Scott, 2001)

3.1 Could you identify the main ones?

3.2 In your experience, can the requirements concerning the Decree $118 / 2011$ contribute to the better comprehension and management of the existing issues? If yes, how?
2.2 Yes, it can. The consolidated financial statements should be able to support the financial position with LGs' subsidiaries.

The integrated chart of accounts should be better able to consolidate the accounts of the LGs' subsidiaries and it can contribute to improving the relation with the Ministry in regards to the accounts' consolidation

3.1 The issues are mainly attributable to unpaid commitments (residui passivi) and uncollected revenue (residui attivi).

However, some elements of the reform on the harmonisation have already been included in other reforms. Sometimes, the reforms seem not to be connected. I am referring to the decree on spending review, which anticipated the remeasurement of the uncollected revenue.

3.2 The current reform contributes to have a clearer picture of the existing issues, but it cannot give a solution to the problems.

The introduction of consolidated financial statements can support a more transparent clarification of the real health of the LG.

Lastly, the harmonisation can help comprehend financial statements, as well as accompany financial statements with a set of adequate indicators.

\begin{tabular}{ll}
\hline $\begin{array}{l}\text { B. Internal } \\
\text { dynamic }\end{array}$ & Question \\
\hline $\begin{array}{l}\text { 1. Political } \\
\text { component and } \\
\text { cultural attitude }\end{array}$ & 1. $\begin{array}{l}\text { Can you describe the implementation } \\
\text { process of the new accounting mode } \\
\text { provided by the Decree 118/2011? }\end{array}$ \\
$\begin{array}{l}\text { Hinings and } \\
\text { Greenwood 1988, } \\
\text { Burns and } \\
\text { Scapens, 2000 }\end{array}$ \\
$\begin{array}{l}\text { 1.1. What has been done? (Burns and } \\
\text { Scapens 2000) }\end{array}$
\end{tabular}

Answer dynamic

1. Political component and cultural attitude
1.1 There are more things to do than things being done. The new financial statements items have been codified, moving from the current chart of accounts based upon chapters, into the new integrated chart, which recognise the items belonging to both the models.

The old financial statements chapters (and consequently, the financial statements) have been re-classified into the new plans organized by missions and programs. The new 2012 budget has been prepared only for the Council's information; the authorization model is based 
1.2. What has to be done?

1.3 What offices have been involved? (Burns and Scapens 2000? What attitude did the people involved in the process have?

(Hinings and Greenwood, 1988; Greenwood and Hinings, 1996)

1.4 Have initiatives been organized to train the personnel? (Burns and Scapens 2000) - If yes, what results have these initiatives had?

1.5 What was the role of the Board members in the implementation phase of the reform? (DiMaggio and Powell, 1983)

1.6 What was the role of politicians in the implementation phase of the reform? (DiMaggio and Powell, 1983) upon the current budget model.

Starting in 2013, the new cash basis of accounting has been applied in the day-by-day operations as well.

1.2 The most challenging part is the remeasurement of the unpaid commitments and uncollected revenue. It was not possible to do this operation before, because 2011 financial statements were approved on the 18th July 2012. The codification into the new formats has been relatively simple. Now, it is time to adjust the management model and to allocate the future receipts and disbursements based on the new model (see also 2.7).

There are implementation issues; for instance, some procedures -and consequently the software program- related to cash and collection orders are to be modified, in order to provide the LG's treasurer deeper information.

1.3 The administrative office has been involved. They were not particularly enthusiastic of this decision. We have prepared two internal directives, then sent to the Minister.

The administrative office is composed of eight people. Likely, this operation would require a higher number of human resources.

1.4 The LG has organized a training course in favour of the administrative office, other departments' officers and other LGs' representatives (four hours). It was probably necessary to dedicate more time to the training activity; unfortunately, the day-by-day operations require much time and this intention was not realizable.

We have had some informal conversations among the different involved offices.

1.5 None

1.6 It is difficult to explain to politicians the reason for which the budget under the new rules had such a high financial surplus. A high financial surplus can be considered as an indicator of inefficiency in the use of financial resources. In this case, it is important to fully explain that the financial surplus results from the application of new accounting standards and from the combined reduction of unpaid commitments (residui passivi) and uncollected revenues (residui attivi). From this perspective, I think it could be useful to prepare a technical report in which we determine the financial surplus applying the old accounting standards, in order to allow the political management to express a 
judgment on the City's management, irrespective from the mentioned accounting changes"

\section{Organization \\ Burns and \\ Scapens, 2000, \\ Burns and \\ Baldvinsdottir, 2005}

2.1. Has the Accounting Regulation been changed? If yes, how? (Burns and Scapens, 2000)

\subsection{Has the software been} modified/changed? If yes, how? (Burns and Scapens, 2000)

2.3 Has the LG had any changes in the organizational structure?

2.4 Has the LG had any changes in its procedures? Which ones? (Burns and Scapens, 2000)

2.5 In your opinion, have the new accounting requirements modified the LG's managerial approach or purpose, and/or the governing principles? (Hinings and Greenwood, 1988; Greenwood and Hinings, 1996)

2.6 Is the reform meant to be a "revolution" or a development of the current model?
2.1 The Accounting Regulation has been changed. It could have been changed at the end of the experimentation. The $L G$ decided a modification of the Regulation, as the decree 174/2012 (regarding new rules on LGs' internal controls) required a modification of the Accounting Regulation as well. In this context, it was decided to propose new changes embodying those arising from the experimentation.

2.2 The previous software has been adapted to the new rules. We opted for the easiest path.

2.3 No. We have not had any changes

2.4 The changes of the LG's procedures have been light and aimed at updating the previous model to the technical adoption of the new requirements (see also A.1.2).

2.5 No. There have been no change in these features.

2.6 The reform is designed as an evolution of the current model. 


\begin{tabular}{lll}
\hline $\begin{array}{l}\text { C Technical } \\
\text { issues }\end{array}$ & Question & Answer \\
\hline
\end{tabular}

$\begin{array}{ll}\begin{array}{l}\text { 1. Changes in } \\ \text { respect to the past }\end{array} & \begin{array}{l}\text { Do you believe that the new accounting } \\ \text { requirements could have a significant } \\ \text { impact (Tsamenyi, Cullen, and } \\ \text { Gonzalez, 2006)? }\end{array} \\ 1.1 \begin{array}{l}\text { Do you think that the new accounting } \\ \text { requirements can have significant } \\ \text { effects on any accounts or the } \\ \text { administrative management? }\end{array}\end{array}$

2. The process of convergence with/divergence towards IPSAS

1.2 Do you believe that the appropriate adoption of the new requirements could depend upon the LGs' technical capacity and by their will to appropriately pursue the information benefits? (Tsamenyi, Cullen, and Gonzalez, 2006)

2 Do you think that the requirements are technically shared?

2.1 Do you believe that the accrual basis of accounting could have a more relevant application?

2.2 In your opinion, is the provision of detailed accounting standards technically adequate?

2.3 Do you believe that LGs' accounting requirements should converge towards those internationally accepted accounting models?

2.4 Is the consolidated financial statements' preparation useful? If yes, why?
1.1 As already stated, the proposed accounting requirements imply a reduction of the impact of the unpaid commitments.

The reduction of uncollected payments is an aspect, which is sometimes underestimated. The current Accounting Standard is very detailed and clarifies some issues dealt with in the current accounting standards issued by the Osservatorio (see also A.2.1 and A.3.1)

Up today, our duty has been relatively simple, even if the experimentation is quite challenging. In order to complete the adoption of the reform, we have to allocate the future receipts and disbursements according to the technical rules provided by the new model (see also 1.2.).

2.1 Yes, I do. Even if I would like to observe that the accrual basis of accounting should be mixed and coordinated with the modified cash basis of accounting, which expresses and will represent, with the experimentation, the authorization system. It is not always correct to relate the improvement of LGs' transparency with external parties by emphasizing the role of the accrual accounting; even the cash basis of accounting can be transparent, but today its role is internally oriented.

2.2 Yes, it is, specially in respect to the allocation of receipts and payments in the LGs' management.

2.3 Yes, I do. A higher harmonisation could further improve the accountability and solve problems by accepted practices.

2.4 Yes, it is. It enhances the comprehension of the "group", even if consolidated financial statements will be applicable starting from 2013. Today, the "individual" financial statements provides a limited information. In this context, it will be possible to determine the receivables and payables with LGs' subsidiaries and create a unique chart of accounts. 